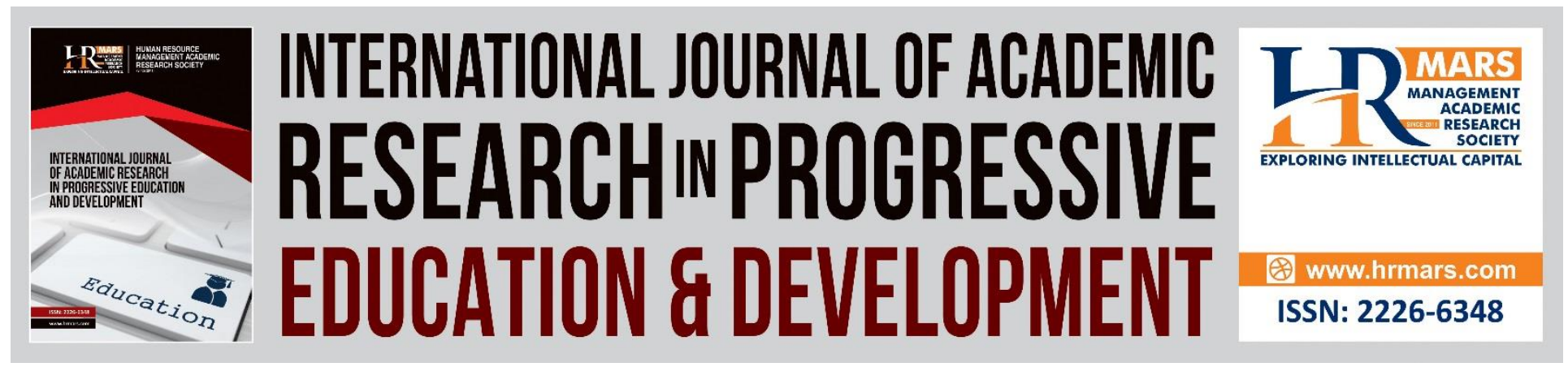

\title{
Relationships Between World Skills Standards Specification (WSSS) And Career Maturity Among Final Year Mechatronics Engineering Students
}

Khairunisa Mohd Kadir, Muhd Khaizer Omar

To Link this Article: http://dx.doi.org/10.6007/IJARPED/v10-i1/8488

DOI:10.6007/IJARPED/v10-i1/8488

Received: 01 January 2021, Revised: 28 January 2021, Accepted: 17 February 2021

Published Online: 17 March 2021

In-Text Citation: (Kadir \& Omar, 2021)

To Cite this Article: Kadir, K. M., \& Omar, M. K. (2021). Relationships Between World Skills Standards Specification (WSSS) And Career Maturity Among Final Year Mechatronics Engineering Students. International Journal of Academic Research in Progressive Education and Development, 10(1), 208-219.

Copyright: (c) 2021 The Author(s)

Published by Human Resource Management Academic Research Society (www.hrmars.com)

This article is published under the Creative Commons Attribution (CC BY 4.0) license. Anyone may reproduce, distribute, translate and create derivative works of this article (for both commercial and non-commercial purposes), subject to full attribution to the original publication and authors. The full terms of this license may be seen at: http://creativecommons.org/licences/by/4.0/legalcode

Vol. 10(1) 2021, Pg. 208 - 219

Full Terms \& Conditions of access and use can be found at http://hrmars.com/index.php/pages/detail/publication-ethics 


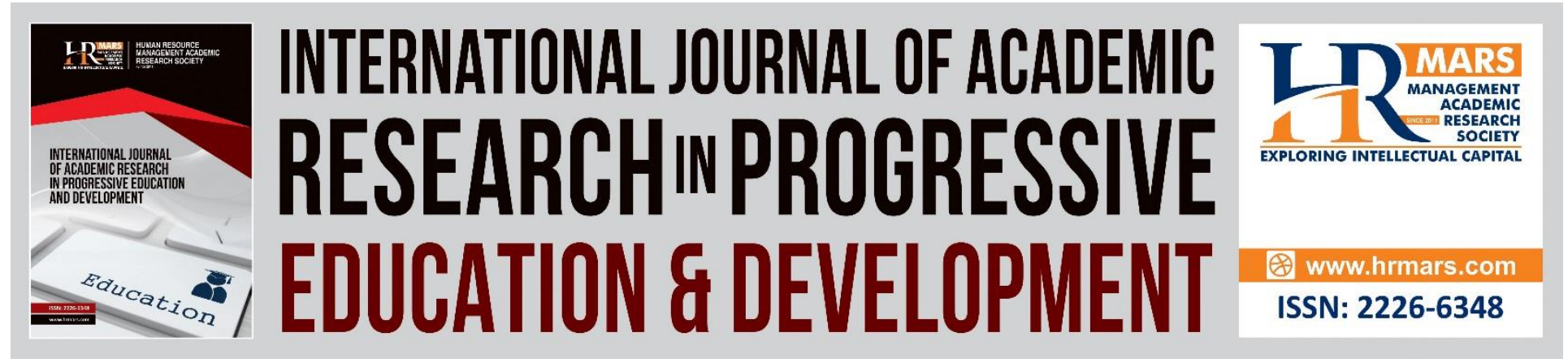

\title{
Relationships Between World Skills Standards Specification (WSSS) And Career Maturity Among Final Year Mechatronics Engineering Students
}

\author{
Khairunisa Mohd Kadir, Muhd Khaizer Omar \\ Department of Science and Technical Education, Universiti Putra Malaysia, Malaysia \\ Email: khairunisakadir0211@gmail.com, khaizer@upm.edu.my
}

\begin{abstract}
The purpose of this paper is to find out the relationship between world skills standards specification (WSSS) and career maturity among final year mechatronics engineering students. This study was conducted in one university in Malaysia. A convenient sample of 80 final year students majoring in Mechatronics Engineering was selected from one public university. Work management and organization skill, interpersonal and communication skill, information and documentation skill, software programming and schematic circuit skill were the elements used as variables of world skills standard specification. Career Maturity Inventory adapted from (The Career Maturity Inventory - Revised; Crites \& Savickas, 1996) serving as the dependent measure and a set of questionnaire was used as instrument in quantitative research to collect the data. The result showed that there is negative relationship between career maturity and interpersonal and communications skill. However, there were not statistically significant between career maturity and work management and organization skill, information and documentation skill and software programming and schematic circuit skill. Only limited correlation was found therefore it was concluded that there is no relationship between world skills standard specification and career maturity. This paper offers knowledge extension and recommendations for practice and research.
\end{abstract}

Keywords: World Skills Standard Specification (WSSS), Career Maturity Inventory, Mechatronics Engineering

\section{Introduction}

The obvious route of career in this twenty first century is most likely to be in technology and engineering field. Having the right technical and management skills for job candidates will absolutely enhance their self-readiness to enter working sector. Mechatronics engineering is a field of study combining few engineering principles such mechanical, electrical and electronics, software and networking. This field offers wide career choice in industry. According to Super 
(1969), the undergraduate period is an important phase that explores and shapes one's career, and that serves as transition from school to the world of work. Thus, final year students are individuals that shall be ready to enter working sector with appropriate abilities and skills.

World Skills Standards Specification (WSSS) is a specification was constructed as instrument to measure the skills and abilities of participants in WorldSkills Competition. The WSSS specifies the knowledge, understanding and specific skills that promote international best practice in technical and vocational skills. Besides, this specification indicates what the associated work roles or occupation represent in world industry. All the skills listed in the specification are very important in developing the career path and maturity of every individual. Elements such as work management and organization skill, interpersonal and communications skill, information and documentation skill, software programming and schematic diagram skill are the elements constructed in the specifications to measure the abilities of participants.

In order to make a better career choice, an individual must have certain level of career maturity and abilities in that career field. A person that has engaged to the career-related activities and experienced the career real life will have a better career maturity. To some extent, the degree of career maturity is determined by the readiness of the individual to make informed, ageappropriate career decisions and cope with appropriate career decisions and cope with appropriate career developmental tasks (Savickas, 1984). In 1978, Crites developed Career Maturity Inventory to assess attitude and competencies of children and adolescents. Career Maturity Inventory has been widely used by researchers to examine the level of career maturity, differences of career maturity with career indecision, and relationship of career maturity and other variables. In one research, the result found that students with lower level of career maturity were more likely to experience higher level of career indecision (Mahdi Khasmohammadi, 2018).

\section{Problem Statement}

The Future Jobs Report from World Economic Forum has recorded panorama of market demand working field in coming years. More than one third (36\%) of all jobs across industries are expected to require technical skills in the future jobs. According to Yei Mei Heong et. al. (2019), the findings shows that the level of readiness of final year technical students from vocational colleges working towards the employability in terms of knowledge, skills and attitude are high. However, there is gap in the research which is the relationship of this employability skills and career maturity is still unknown. Furthermore, the level of the skills measure in the study is unreachable to the world skills standards specification. Career maturity render people capable of determinining their career path. Furthermore, a student who knows about which career path she/he will be taken will be more capable to equip themselves with the necessary skills and experiences. (Van Reenen, 2010). Therefore, it is important to study the relationship between skills related to technical and career maturity of the students. However, little research has been conducted in the area of career maturity among engineering students and the relationship to the technical skills. Hence, this study intends to examine the relationship between world skills standards specification and its elements with career maturity. 
INTERNATIONAL JOURNAL OF ACADEMIC RESEARCH IN PROGRESSIVE EDUCATION AND

DEVELOPMENT

Vol. 10, No. 1, 2021, E-ISSN: 2226-6348 @ 2021 HRMARS

\section{Objectives}

The objectives of this study are as stated below:

1. To determine the relationship between work management and organization skill and career maturity.

2. To determine the relationship between interpersonal and communication skill and career maturity

3. To examine the relationship between information and documentation skill and career maturity

4. To examine the relationship between software programming and schematic circuit skill and career maturity

5. To investigate the relationship between world skills standard specification (WSSS) and career maturity.

\section{Significance of the Study}

The significance of this study is to help to improve the abilities of technical skills among engineering students to cope with career maturity of every individual hence will develop career readiness and increase the ability to choose the right career.

\section{Conceptual Framework of the Study}

Conceptual framework of this study consists of five independent variables and one dependent variable. Work management and organization skill, interpersonal and communications skill, information and documentation skill, software programming and schematic circuit skill, and world skills standards specification (WSSS) are the independent variables for this research study while dependent variable is the career maturity. 


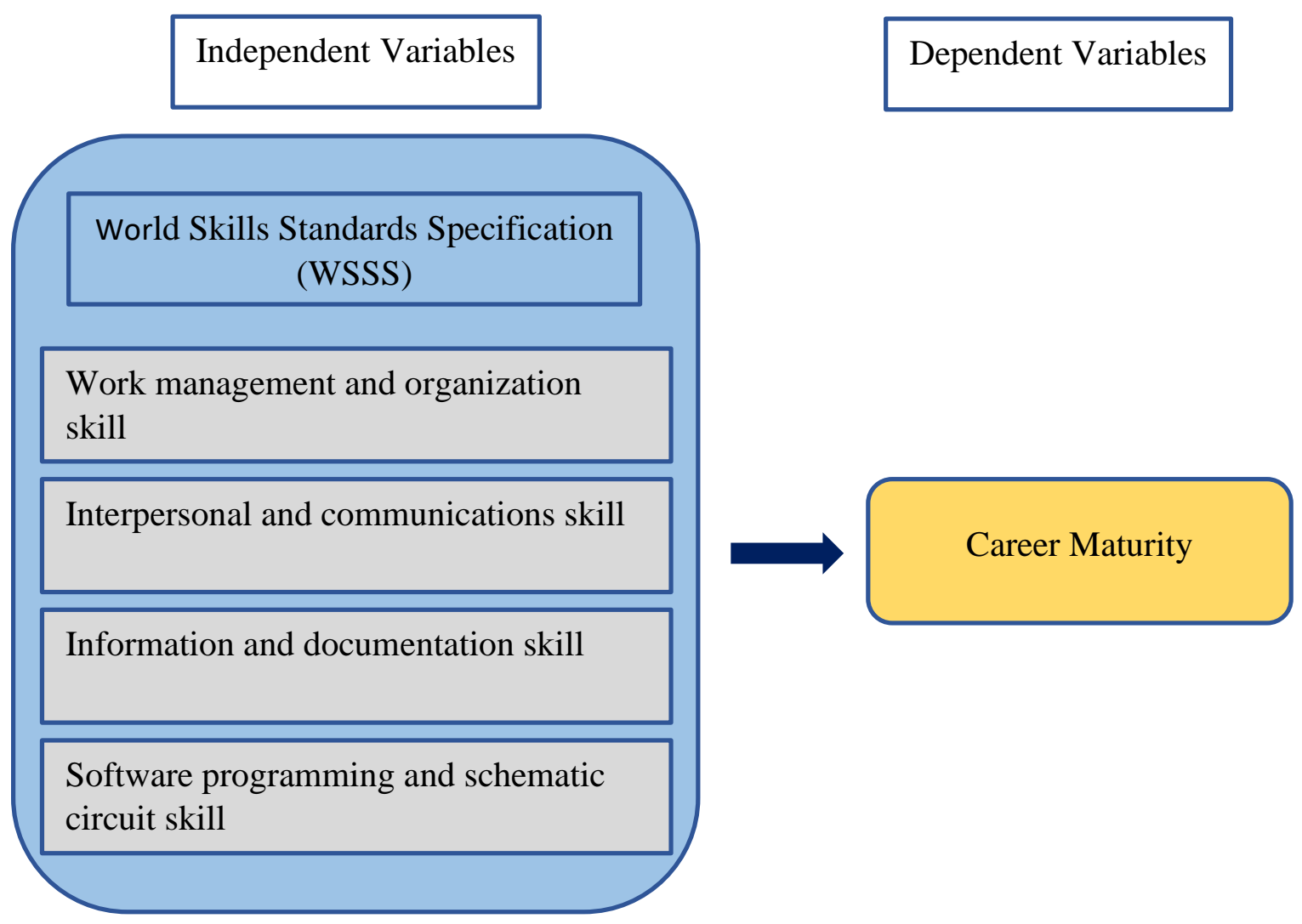

\section{Career Maturity Theory}

Crites (1978) defined career maturity as the degree of students' progress for engaging, making career choices independently, preserving eagerness, and understanding the process of choosing career. Super (1990) defined career maturity when an individual is ready to carry out the developmental tasks which he or she is expected to do since he or she is biologically and socially developed and is able to demonstrate the behavior which is expected by society. Career maturity was an important concept at institution of higher learning because most colleges required their students to make a college major choice even if the students were not developmentally ready (Virginia \& Steele, 2015).

Personal skills, educational abilities, and decision making skill about the world of work form cognitive domain (Crites, 1965, 1971, 1978; Nilsson, Schmidt, \& Meek, 2002). According to the above classification, when university students do not have career maturity before leaving school and graduation, they lack sufficient information about career choices, do not understand their own aptitudes, interests and major, and are often hopeless and desperate, unsatisfied, and unsuccessful (Huang, 2003; Yang \& You, 2010).

\section{Methodology}

This research was basically quantitative method and utilized using descriptive and correlational research design. Descriptive analysis used to give a description of age, sex and types of working 
Vol. 10, No. 1, 2021, E-ISSN: 2226-6348 @ 2021 HRMARS

sector, work value and skill chosen by respondents. Correlational research design used to determine the relationship between a dependent variable and five independent variables.

\section{Sampling Procedure}

Final year students were targeted respondents as they were gone through industrial training and soon to be a worker. A purposive sampling was used to determine field of study of respondents which is meant to be Mechatronics Engineering. There are 20 public universities in Malaysia however only 16 offered engineering courses to undergraduate students. Therefore, from 16 universities, only five were offering Mechatronic Engineering course. The names of universities are: Universiti Sains Malaysia, Universiti Islam Antarabangsa Malaysia, Universiti Teknikal Melaka, Universiti Malaysia Pahang and Universiti Malaysia Perlis. At this stage, random sampling was utilized to select one university and Universiti Malaysia Pahang was selected randomly. The population of final year Mechatronics students was 107 students. 80 students of sample size were determined based on Krejcie and Morgan's sample size determination table (Krejcie \& Morgan, 1970).

\section{Instrument}

A set of questionnaire consist of six section was developed as research instrument. Demographic information was utilized to measure age, sex, working sector, work value, and chosen skill. Whereas Section B, C, D, E was utilized for elements in World Skills Standards Specification (WSSS) adapted from World Skill Competition 2019 specification format specifically in Mechatronics field. It consists of 32 questions which allocate 8 questions for every section. Likert scale ranging from (1) Low ability, (2) Some ability, (3) Adequate ability, (4) More than adequate ability, (5) High ability were used to measure skill abilities of respondents. Career Maturity Inventory-Revised (CMI-R; Crites \& Savickas, 1996) was extremely used by researchers to measure career maturity. In this research, Career Maturity Inventory was adapted from previous study (Mahdi Khasmohammadi, 2018) and amended as appropriate to the research. It is consisting of 30 questions ranging from (1) Strongly disagree, (2) Disagree, (3) Slightly agree, (4) Agree, (5) Strongly agree to measure career maturity of respondents.

\section{Data Analysis Procedure}

A descriptive statistic shall be conducted to describe demographical data of the respondents. Then, a normality test is run as prerequisite to determine appropriate type of statistical test which underlying either parametric or non-parametric statistics. Kolmogorov-Smirnov test and Shapiro-Wilk test were used to assess the normality of the data collected. All the data was considered normal distribution if the sig. value of the Shapiro-Wilk test is greater than 0.05 . Therefore, if the data is parametric statistics and Pearson Product Moment Correlation will be conducted to examine the correlation between independent variables and dependent variable. The data is then key-in SPSS Statistics V24 software and run appropriately to obtain the result findings. 


\section{Findings and Discussion}

A few findings were obtained from the data collected in this research. There are descriptive findings which included frequencies of female and male respondents and respondent's age. Mean, standard deviation, min and max of chosen working sector, work value and skill were also found in this study. Furthermore, correlational analysis showed the relationship between four elements in World Skills Standards Specification and Career Maturity.

\section{Descriptive Findings}

i. Frequency and percentage of respondent's sex and age involved in this study were obtained. The findings show that female respondents $(52.5 \%)$ are higher than male respondents (47.5\%). Moreover, age of the respondents lies between youngest 22 years old and oldest 27 years old which 23 years old became highest frequency (44 respondents) among all. Details of the findings were presented in the table below.

\begin{tabular}{cccc}
\hline & Demographic Information & Frequency & Percentage (\%) \\
\hline \multirow{2}{*}{ Sex } & Male (1) & 38 & 47.5 \\
& Female (2) & 42 & 52.5 \\
\hline 22 & 10 & 12.5 \\
23 & 44 & 55.0 \\
Age & 24 & 20 & 25.0 \\
& 25 & 4 & 5.0 \\
& 26 & 1 & 1.3 \\
& 27 & 1 & 1.3 \\
\hline
\end{tabular}

Table 4.1.1 Demographical Information on respondent's sex and age

ii. In this study, chosen working sector, work value and skill were measured to know their interest towards desired working environment of respondents. List of working sector related to Mechatronics Engineering was developed in questionnaire such as engineering management, research and development, mechanical, electrical and electronics, software and IT and manufacturing. The result shows that most of respondents chose to be in mechanical (27.5\%) and electrical and electronics (31.3\%) sector. In addition, six work values including achievement, recognition, freedom, work state, relationship and support were adapted from O.net resource center (onetcenter.org) that has valid data as source of occupational information. Result obtained from this element shows that support $(22.5 \%)$ is the highest work value chosen among respondents. There are a lot of skill gained by a mechatronics engineering student such as CAD design, electrical installation, electronic circuit design, software development, mechanical installation and testing and evaluation. To know what skill is the most interest skill for them, this characteristic was included in research instrument. The finding in table below recorded mechanical installation $(31.3 \%)$ is the most chosen skill. 
INTERNATIONAL JOURNAL OF ACADEMIC RESEARCH IN PROGRESSIVE EDUCATION AND DEVELOPMENT

Vol. 10, No. 1, 2021, E-ISSN: 2226-6348 @ 2021 HRMARS

\begin{tabular}{llcc}
\hline & Characteristics & Frequency & Percentage (\%) \\
\hline \multirow{4}{*}{ Working sector } & Engineering management & 1 & 1.3 \\
& Research \& development & 4 & 5.0 \\
& Mechanical & 22 & 27.5 \\
& Electrical \& electronics & 25 & 31.3 \\
& Software \& IT & 19 & 23.8 \\
& manufacturing & 9 & 11.3 \\
\hline \multirow{4}{*}{ Work value } & Achievement & 9 & 11.3 \\
& Recognition & 12 & 15.0 \\
& Freedom & 17 & 21.3 \\
& Work state & 8 & 10.0 \\
& Relationship & 16 & 20.0 \\
& Support & 18 & 22.5 \\
\hline \multirow{4}{*}{ Skills } & CAD design & 11 & 13.8 \\
& Electrical installation & 12 & 15.0 \\
& Electronics circuit & 13 & 16.3 \\
& Software development & 11 & 13.8 \\
& Mechanical installation & 25 & 31.3 \\
& Testing and evaluation & 8 & 10.0 \\
\hline
\end{tabular}

Table 4.1.2 Frequency and percentage of working sector, work value and skill

\section{Correlational Analysis}

i. Relationship between work management and organization skill and career maturity among final year Mechatronics Engineering students.

\begin{tabular}{lccccc}
\hline \multicolumn{1}{c}{ Variables } & $\mathrm{N}$ & Mean & SD & r & Sig-r \\
\hline $\begin{array}{l}\text { Work Management } \\
\text { and Organization Skill }\end{array}$ & 80 & 2.953 & .445 & & \\
$\begin{array}{l}\text { Career Maturity } \\
\text { Inventory }\end{array}$ & 80 & 1.502 & .164 & .163 & .149 \\
\hline
\end{tabular}

Table 4.2.1 Correlation between work management and organization skill and career maturity

According to the table 4.2.1, most of respondents have some ability in work management and organization skill (mean $=2.953$ ). However, there was no relationship between work management and organization skill and career maturity $(r=.163$, sig- $r=.149)$. These findings were slightly different from study made by Wendy, P \& Peter, A. C. (2002) that resulted a strong relationship between work commitment and career maturity among female high school students. 
Vol. 10, No. 1, 2021, E-ISSN: 2226-6348 @ 2021 HRMARS

ii. Relationship between interpersonal and communications skill and career maturity among final year Mechatronics Engineering students.

\begin{tabular}{lccccc}
\multicolumn{1}{c}{ Variables } & $\mathrm{N}$ & Mean & SD & $\mathrm{r}$ & Sig-r \\
\hline $\begin{array}{l}\text { Interpersonal and } \\
\begin{array}{l}\text { Communications Skill } \\
\text { Career Maturity }\end{array}\end{array}$ & 80 & 2.979 & .355 & & \\
$\begin{array}{l}\text { Inventory } \\
\text { *Correlation is significant at level of significance }=.05\end{array}$ & 80 & 1.502 & .164 & & \\
\hline
\end{tabular}

Table 3.2.2 Correlation between interpersonal and communications skill and career maturity

Result indicated in Table 4.2.2 shows that there was a negative relationship between interpersonal and communications skill and career maturity $(r=-.230$, sig- $r=.040)$. There was a small relationship between interpersonal and communications skill and career maturity according to Cohen's rule because $r$ value $=-.230$ lies between .1 and .3 (Cohen, 1977). Thus, the result shows that even though students has good interpersonal and communication skills, they are lacking in career maturity. It is supported by the research from (Iksan et.al. 2011) that found out university students have achieved good communication skill. However, it is not consistent to a research from Siddiqi et al (2015) that found a positive relationship between interpersonal skill and career development. It is obvious that to mature in a career, ones need to improve in other aspects other than interpersonal and communication skill.

iii. Relationship between information and documentations skill and career maturity among final year Mechatronics Engineering students.

\begin{tabular}{|c|c|c|c|c|c|}
\hline Variables & $\mathrm{N}$ & Mean & SD & $r$ & Sig- $r$ \\
\hline $\begin{array}{l}\text { Information and } \\
\text { Documentations skill }\end{array}$ & 80 & 2.989 & .353 & \multirow{2}{*}{.047} & \multirow{2}{*}{.678} \\
\hline $\begin{array}{l}\text { Career Maturity } \\
\text { Inventory }\end{array}$ & 80 & 1.502 & .164 & & \\
\hline
\end{tabular}

Table 4.2.3 Correlation between information and documentations skill and career maturity

Table 4.2.3 indicated no relationship between information and documentations skill and career maturity $(r=.047$, sig- $r=.678)$. Therefore, information and documentations skill has less effect on career maturity development in every individual.

iv. Relationship between software programming and schematic circuit skill and career maturity among final year Mechatronics Engineering students. 
Vol. 10, No. 1, 2021, E-ISSN: 2226-6348 @ 2021 HRMARS

\begin{tabular}{lccccc}
\multicolumn{1}{c}{ Variables } & N & Mean & SD & $r$ & Sig-r \\
\hline $\begin{array}{l}\text { Software Programming } \\
\text { and Schematic Circuit } \\
\text { skill }\end{array}$ & 80 & 3.004 & .354 & & \\
$\begin{array}{l}\text { Career Maturity } \\
\text { Inventory }\end{array}$ & 80 & 1.502 & .164 & & .002 \\
\hline
\end{tabular}

Table 4.2.4 Correlation between software programming and schematic circuit skill and career maturity

The result obtained in Table 4.2.4 shows that there was no relationship between software programming and schematic circuit skill and career maturity $(r=.047$, sig- $r=.678)$ with significance level. Therefore, the ability in software programming and schematic circuit does not involve in career maturity development.

v. Relationship between world skills standards specification (WSSS) and career maturity among final year Mechatronics Engineering students.

\begin{tabular}{|c|c|c|c|c|c|}
\hline Variables & $\mathrm{N}$ & Mean & SD & $r$ & Sig- $r$ \\
\hline $\begin{array}{l}\text { World Skills Standards } \\
\text { Specification (WSSS) }\end{array}$ & 80 & 2.981 & .210 & \multirow[b]{2}{*}{-.194} & \multirow[b]{2}{*}{.084} \\
\hline $\begin{array}{l}\text { Career Maturity } \\
\text { Inventory }\end{array}$ & 80 & 1.502 & .164 & & \\
\hline
\end{tabular}

Table 4.2.5 Correlation between World Skills Standards Specification (WSSS) and career maturity

Findings in Table 4.2.5 indicated that there was no relationship between World Skills Standards Specification (WSSS) and career maturity $(r=-.194$, sig- $r=.084)$. Based on this result, it can be concluded that world skill standards specification is not significantly correlated with career maturity of the final year Mechatronics Engineering students.

\section{Conclusion}

The findings of this study show that the number of female students is higher than male students. Age of the final year students can be concluded ranging from 22 years old to 27 years old in this research. Furthermore, Mechatronics Engineering students most likely to be interested more in mechanical sector and mechanical skill than other sectors and skills. Respondents are looking at work values such as support and freedom to enter the working sector in future. Supportive management that stands behind employees and a freedom or democratic organization would lead to a better working environment. 
In this study, the correlational between world skills standards specification (WSSS) and career maturity were not found to be statistically significance. However, a relationship was obtained between an element in WSSS which is interpersonal and communications skill and career maturity. Although a statistically significant correlation was found between this variables, the size of correlation (-.230) indicates a negative and weak relationship which accounts an inverse relationship between interpersonal and communication skill and career maturity. Although the overall communication skills among university students are good, there are still certain aspects that are not up to the expectations of potential employers (Misdi, et al. 2010).

The lack of relationship between these two instruments can be improved in some other way. Because the credibility of any research conclusions about career maturity is dependent upon the reliability and validity of the measuring instrument, it was important to determine and/or to establish the reliability and validity of measures used in this study (Eleanor \& Miriam, 1990). In a conclusion, students shall be provided with correct measurement to know their abilities, interests, and values to equip them to enter working sector and prevents career immature.

\section{Research Contributions}

The empirical findings contribute to the understanding of the relationship between world skills standards specification (WSSS) and career maturity. This study also offered contribution to our understanding of elements related to the WSSS and career maturity.

The findings of this study suggest that final year students are still lack in career maturity and world skills standards specification such as work management and organization skill, interpersonal and communications skill, information and documentation skill, software programming and schematic diagram skill. Therefore, teachers and management are responsible to make and effort towards this issue in developing a strong career maturity and related skills in final year students.

The other contribution made by this study is the findings on inverse and weak relationship between interpersonal and communication skill and career maturity. This could be a pathway to look deeper in this situation and to choose different approach in the future. Nowadays, it is very real that our students are facing interpersonal and communication skill problem even though they are ready to enter working life. Therefore, the findings contribute to the other researchers to look further at the situation in most suitable method.

\section{References}

Siddiqi, Z., Nasim, S., Hussain, A., \& Basit, S. A. (2015). Relationship between Interpersonal Skills, Analytical Skills and Career Development. International Journal of Management Sciences and Business Research, 4, 14.

Azeem, N., Omar, M. K. (2018). Relationships Between Occupational Stress, Organizational Commitment and Teacher Performance at University Level in Pakistan. Graduate Research in Education Seminar (Greduc) 2018, Selangor, Malaysia. 
INTERNATIONAL JOURNAL OF ACADEMIC RESEARCH IN PROGRESSIVE EDUCATION AND

DEVELOPMENT

Vol. 10, No. 1, 2021, E-ISSN: $2226-6348$ @ 2021 HRMARS

Crites, J. O., \& Savickas, M. L. (1996). Revision of the Career Maturity Inventory. Journal of Career Assessment, 4, 131-138.

Busacca, L. A., \& Taber, B. J. (2002). The Career Maturity Inventory-Revised: A Preliminary Psychometric Investigation. Journal of Career Assessment, 10(4), 441-455.

Savickas, M. L., \& Porfeli, E. J. (2011). Revision of the Career Maturity Inventory: The Adaptability Form. Journal of Career Assessment, 19(4), 355-374.

Kılıçoğlu, N. A. (2015). The Relationship Between Vocational Maturity and Hopelessness Among Female and Male Twelfth Grade Students (Master's thesis, Marmara University, Istanbul, Turkey).

Westbrook, B. W. (1985). What Research Says about Career Maturity: A Response to Crites, Wallbrown and Blaha. (1985). Journal of Vocational Behavior, 26, 239 - 250.

Adelstein, D. M., \& Webster, D. W. (1979). Cross-Sectional, Longitudinal and Composite Longitudinal Data on the Career Maturity Inventory Attitude Scale. Journal of Vocational Behavior, 14, 102 - 111.

Nevill, D. D., \& Super, D. E. (1988). Career Maturity and Commitment to Work in University Students. Journal of Vocational Behavior, 32, 139 - 151.

Birol, C., \& Kiralp, Y. (2010). A comparative analysis of the career maturity level and career indecision of the first grade high school students. Procedia Social and Behavioral Sciences, 5, 2359 - 2365. doi:10.1016/j.sbspro.2010.07.464

Kuchinke, K. P., Kang, H. S., \& Oh, S. Y. (2008). The Influence of Work Values on Job and Career Satisfaction, and Organizational Commitment among Korean Professional Level Employees. Asia Pacific Education Review, 9(4), 552 - 564.

Gasper Jr, T. H., \& Omvig, C. P. (1976). The Relationship between Career Maturity and Occupational Plans of High School Juniors. Journal of Vocational Behavior, 9, 367 - 375.

Westbrook, B. E., \& Sandford, E. E. (1990). The Relationship between Career Maturity Test Scores and Appropriateness of Career Choices: A Replication. Journal of Vocational Behavior, 36, $20-32$.

Tekke, M., \& Ghani, A. M. F. (2013). Examining The Level of Career Maturity Among Asian Foreign Students in A Public University: Gender And Academic Achievement. Hope Journal of Research, 1(1), 100 - 121.

Moradi, S., Faghiharam, B., \& Ghasempour, K. (2018). Relationship Between Group Learning and Interpersonal Skills with Emphasis on the Role of Mediating Emotional Intelligence Among High School Students. SAGE Open Journal, 8(2), 1-10.

Jalaludin, M. A. M., \& Ihkasan, M. N. (2014). Interpersonal Communication Skills among the Master's Students in TVET. Journal of Developing Country Studies, 4(16), 110-118.

Zainuddin, A. A. Z., \& Selamat, S. (2012). Efficacy of Polytechnic students' Interpersonal Communication Skills. Advances in Language and Literary Studies, 3(2), 76-86.

Heong, Y. M., Sharberi, S. N. M., \& Pauzan, M. F. A. (2019). The Readiness of Vocational College Technical Students for Job Employability. International Journal of Research and Innovation in Social Science (IJRISS), 3(11), 537-541. 